\title{
Zika no Brasil: certezas e incertezas de uma história inacabada
}

\section{Zika in Brazil: certainties and uncertainties in an unfinished story}

\author{
Gabriel Lopes ${ }^{i}$ \\ i Pesquisador em estágio pós-doutoral, Casa de Oswaldo Cruz/Fiocruz. \\ Rio de Janeiro - RJ - Brasil \\ orcid.org/0000-0002-4334-5522 \\ lopes-gabriel@hotmail.com
}

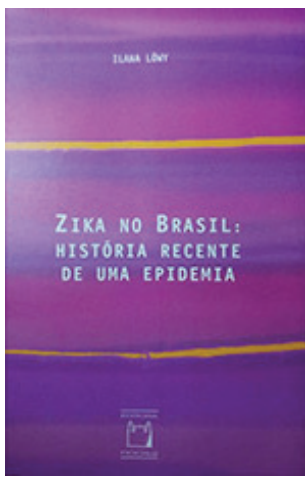

LÖWY, Ilana. Zika no Brasil: história recente de uma epidemia. Rio de Janeiro: Editora Fiocruz, 2019. 171p.
O livro de Ilana Löwy, lançado em 2019 pela coleção Temas em Saúde da Editora Fiocruz, faz um balanço das principais questões de saúde pública envolvendo a epidemia de zika no Brasil a partir de 2015 e a sua relação com os casos de microcefalia. Historiadora das ciências biomédicas e atualmente pesquisadora do Instituto Nacional Científico e de Pesquisa Médica da França (Inserm), Löwy apresenta diferentes ângulos científico-políticos dessa epidemia de forma didática, articulando uma questão fundamental: o que de fato conhecemos sobre a trajetória do vírus da zika no Brasil?

A autora articula as diferentes dimensões em um campo temático com o qual já possui bastante familiaridade. Exemplo disso são seus trabalhos anteriores sobre as práticas científicas e de saúde pública em relação à febre amarela - doença que também é transmitida pelo Aedes aegypti -, (in)visibilidades dos objetos das ciências biomédicas, diagnósticos e direito reprodutivo. Essas abordagens são mobilizadas com naturalidade e fluidez na sua proposta de uma história "recente", como está no título, ou "do presente" e seus desafios (Löwy, 2019, p.13).

Como pesquisadora feminista nascida na Polônia e com uma trajetória internacional que inclui Israel, França, EUA e Brasil, Löwy valoriza elementos comparativos, observando como os problemas de saúde pública são percebidos em diferentes contextos. Dessa forma, reafirma a dimensão incorporada e localmente produzida das práticas científicas como uma marca de sua abordagem.

O livro explora questões recentes abrindo caminho para reflexões mais complexas sobre a história das ciências biomédicas. Oferece ainda um bom mapa introdutório para as principais questões de uma epidemia que estabeleceu um novo marco na história das arboviroses. 
No primeiro capítulo, "Zika e microcefalia", é descrita uma trajetória das epidemias de zika, começando pela descoberta e pelo deslocamento do vírus da África para o sudeste da Ásia e a sua súbita visibilidade com a epidemia na ilha de Yap, em 2007, até a febre misteriosa que atingiu o Nordeste do Brasil, no início de 2015, com os primeiros registros de microcefalia. No segundo capítulo, "Certezas e enigmas do zika", são analisados os desdobramentos de algumas questões que se projetam em âmbito internacional, como a declaração da Emergência de Saúde Pública de Interesse Internacional pela Organização Mundial da Saúde. Ao mesmo tempo, são exploradas as especificidades da epidemia na região Nordeste, o que pavimenta os argumentos da discussão do terceiro capítulo, "Uma epidemia de desigualdade: classe, raça e gênero na época do zika". Este aborda a prevalência da síndrome congênita entre os filhos de mulheres pobres e não brancas, tornando incontornáveis as questões relacionadas à contracepção e ao aborto no Brasil. O quarto capítulo, "Quando uma epidemia acaba", enfatiza os avanços de pesquisadores brasileiros, mas também as incógnitas dessa arbovirose em sua história ainda inacabada.

Apesar das poucas páginas, o livro abrange com rigor técnico diversos assuntos que vão desde a história natural do vírus da zika, problemas de bioética e desigualdades nas relações internacionais nas pesquisas, até importantes condicionantes interseccionais da zika como uma "epidemia de desigualdade" (Löwy, 2019, p.95).

Há trechos provocativos, que expõem a posição de descrédito atribuída à pesquisa sobre zika no Brasil por especialistas estadunidenses, na medida em que "nem todos os pesquisadores ocidentais propuseram uma parceria verdadeiramente justa para seus colegas brasileiros" (Löwy, 2019, p.69). Os sucessos e negligências das cooperações científicas são sopesados por Löwy, porém a clivagem entre a ciência latino-americana e a ocidental é claramente demarcada nas passagens sobre a "'arrogância' dos pesquisadores ocidentais" (p.70), um elemento que certamente pode aquecer importantes discussões no âmbito das assimetrias da história da saúde global.

As ideias do médico e epistemólogo Ludwick Fleck (1896-1961) se apresentam como importantes elementos teórico-metodológicos para compreender os processos de constituição dos fatos científicos nas reflexões de Löwy (2019, p.165). Além disso, a influência do historiador Charles Rosenberg é notória na organização dos enquadramentos propostos, especialmente nos capítulos dois e três, os mais substanciais do livro.

Fica evidente o empenho gregário da pesquisa realizada, na medida em que dialoga de forma sensível e crítica com depoimento de pessoas que pesquisaram, pensaram e que também sofreram diretamente com a epidemia de zika. A autora ressalta a participação das mulheres em todas essas esferas, especialmente em relação aos estudos pioneiros desenvolvidos por pesquisadoras brasileiras. Além disso, ao manter uma cooperação de longa data com pesquisadores de Fiocruz, Löwy também destaca a sua cooperação na Rede Zika Ciências Sociais (RZCS) na pesquisa que forneceu as bases para os estudos apresentados de maneira introdutória no livro.

A cooperação de Löwy na RZCS contribuiu de forma direta para produções no campo da antropologia e história da saúde em diversas perspectivas. Um elemento importante desse diálogo ampliado realizado por Löwy é a compreensão da zika de forma não isolada do problema geral das arboviroses no Brasil. Esse processo histórico também foi explorado em 
seu artigo "Leaking containers: success and failure in controlling mosquito Aedes aegypti in Brazil" (Löwy, 2017).

Essa história pode se definir como "recente", como está no título. Porém, defini-la como "história do presente" (Löwy, 2019, p.13) parece mais justo. As ideias mobilizadas por Löwy, considerando a densidade de problemas e dramas sanitários que permanecem em aberto, "a história de um evento confuso, complexo e muito parcialmente compreendido" (p.159) parece se aproximar, mesmo que de forma implícita, da hipótese do historiador Henry Rousso. Em seu livro que define uma proposta de história do tempo presente, Rousso (2016, p.17, 24) indica que "toda história contemporânea começa com a 'última catástrofe em data'” em um passado que não está acabado, construindo um presente dotado de "espessura", "perspectiva" e "duração", uma operação que, de forma bastante satisfatória, encontra ecos no livro escrito por Löwy.

Uma das grandes contribuições do livro está no seu empenho em não apenas descrever o que se sabe sobre a zika, mas também em delinear os desconhecidos, ou seja, um alerta para um dimensionamento reflexivo da nossa ignorância sobre os enigmas que a circulação desse vírus ainda deixa em aberto na atualidade. Além disso, há um diálogo profícuo com as diversas questões pavimentadas pelo trabalho de pesquisadoras brasileiras como Débora Diniz (2016). Desta forma, Löwy cumpre muito bem o seu objetivo em sintetizar a elusiva trajetória da zika no Brasil não apenas evidenciando, mas reatualizando suas certezas e incertezas.

O livro Zika no Brasil: história recente de uma epidemia, além de fornecer grande contribuição ao campo, com questões atuais e instigantes, também estimula a entrada em importantes campos do conhecimento que vão da saúde pública à reflexão sobre a prática das ciências biomédicas, o que é favorecido por uma excelente lista de sugestões de material de consulta, com livros, artigos, documentários e depoimentos de fácil acesso on-line. $\mathrm{O}$ livro é recomendado para estudantes e profissionais da saúde, público interessado em história das doenças, estudos sociais da ciência, bem como leitores em geral que buscam uma forma acessível de entender um assunto complexo.

\section{REFERÊNCIAS}

DINIZ, Débora. Zika: do sertão nordestino à ameaça global. Rio de Janeiro: Civilização Brasileira, 2016.

LÖWY, Ilana. Zika no Brasil: história recente de uma epidemia. Rio de Janeiro: Editora Fiocruz, 2019.
LÖWY, Ilana. Leaking containers: success and failure in controlling mosquito Aedes aegypti in Brazil. American Journal of Public Health, v.107, n.4, p.517-524, 2017.

ROUSSO, Henry. A última catástrofe: a história, o presente, o contemporâneo. Rio de Janeiro: Editora FGV, 2016. 